\title{
Rektum Kanserinde Nadir Bir Komplikasyon: Dalak Absesi
}

\author{
A Rare Complication of Rectum Cancer: Splenic Abscess
}

\section{Ahmet Demircan, Ayfer Keleş, Gültekin Kadı}

Gazi Üniversitesi Tıp Fakültesi Acil Tıp Anabilim Dalı, Ankara, Türkiye

\section{ÖZET}

Dalak absesinin insidansi çok nadirdir. Operasyon sırasında ve sonrasında gelişen risklere bağlı olarak mortalite ve morbidite oranları değişmektedir. Rektum kanserlerinin komplikasyonları her zaman beklenen semptomlar ile karşımıza çıkmayabilir.Biz bu vakada karın ağrısı ve ateş ile gelen rektum kanseri olan bir hastayı sunacağız. Erken tanının mortalite ve morbidite üzerindeki etkisinden bahsedeceğiz.

Anahtar Sözcükler: Dalak absesi, rektum kanseri

Geliş Tarihi: 31.12 .2015

Kabul Tarihi: 07.09.2016

\section{GiRiş}

Dalak absesi genel popülasyonda oldukça nadir karşılaşılan bir durumdur (1). Sıklıkla altta yatan ek hastalıklar ve travma ile ilişkili olarak gelişmesi daha muhtemeldir. İmmünsüprese, diyabetes mellütis, konjenital ya da kazanılmış immün yetmezliği olan hasta gruplarında daha dikkat etmek gerekmektedir (2).

\section{OLGU SUNUM}

Bilinen rektum kanseri ve 1,5 yıldır olan multipl karaciğer metastazları ile takipli 75 yaşındaki kadın hasta, acil servisimize 2 gündür olan karın ağrısı ve ateş şikayeti ile başvurdu. Diğer ateş odakları açısından anamnezinde belirgin özellik yoktu. Hasta ağrısını sol üst kadranda tariflemekteydi. Yakın zamanda alınan kemoradyoterapi ve cerrahi girişim öyküsü yoktu.

Fizik muayenesinde sol üst kadranda lokalize hassasiyet haricinde belirgin bir özellik bulunmamaktaydı. Hastanın vital bulgularında nabız: 110 atım/dk, TA: $90 / 65 \mathrm{~mm} / \mathrm{Hg}$, ateş: $39^{\circ} \mathrm{C}, \mathrm{SaO}_{2}$ : \%95 idi. Hastanın laboratuvar sonuçlarında wbc: $15000 \mathrm{~K} / \mathrm{uL}$, venöz kan gazında $\mathrm{pH}: 7,222, \mathrm{HCO}_{3}$ : 13, Laktat: 14 idi. Hastanın karaciğer ve böbrek fonsiyon testleri normal sınırlardaydı. PA akciğer grafisinde belirgin özellikte patoloji saptanmadı.

Hastanın ateş ve karın ağrısı etiyolojisini aydınlatmak ve karın içi abse olup olmadığını belirlemek için önce batın USG düşünüldü fakat metastatik kanseri olduğu için daha net ayırıcı tanı yapabilmek amacıyla i.v. opaklı batın bilgisayarlı tomografi çekildi. Bilgisayarlı tomografide daha önceden var olan karaciğerde metastatik alanlar haricinde dalak komşuluğunda en kalın yerinde yaklaşık 2,5cm'e ulaşan abse formasyonu saptandı(Resim 1).

\section{TARTIŞMA}

Dalak abseleri oldukça nadir gelişen klinik durumlardandır. Özellikle altta yatan risk faktörlerine bağlı durumlarda fiziki muayene ve vital bulgular ile değerlendirildiğinde şüphelenilmesi gereken, atlanılması durumunda ise oldukça mortal ve komplikasyonlarla seyredebilen bir durumdur. Dalak absesi ön tanısı olan hastalarda kontrastlı bilgisayarlı tomografi görüntüleme tetkileri içerisinde daha yararlı olmaktadır. USG bazı durumlarda dalak enfarktı ile absesi ayrımını yapmakta zorlanmaktadır(4). Mortaliteleri \%47'ye kadar yükselebilmektedir (3).

\section{ABSTRACT}

Incidence of splenic abscess is a rare. Depending upon the operational risk factors the intra and postoperative morbidity rate vary. Complications of the rectum cancer does not always present with the common symptoms. We present a patient with rectum cancer who presented with features of abdominal pain and fever. Early diagnosis as a goal in this case because of morbidity and mortality.

Key Words: Splenic abscess, rectum cancer

Received: 12.31 .2015

Accepted: 09.07.2016

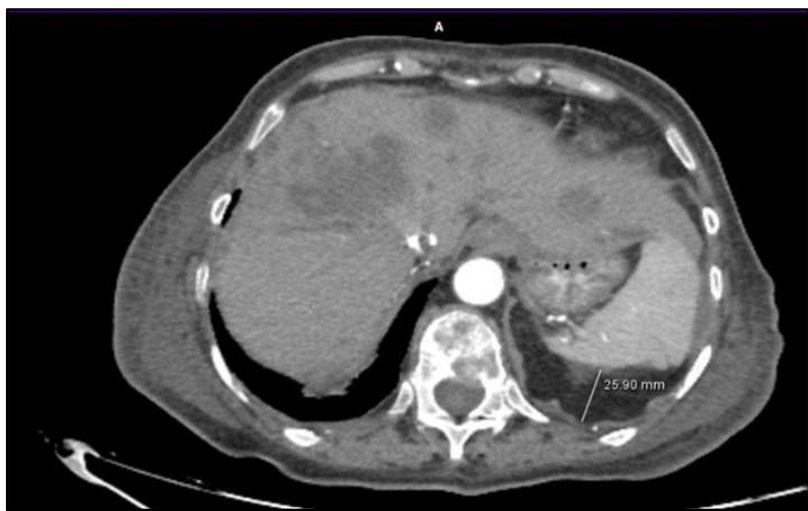

Resim 1: En kalın yerinde $2.5 \mathrm{~cm}$ 'e ulaşan abse alanı

Dalak absesi vakaları oldukça nadir görülebilen bir antite olarak klinikte karşımıza çıkmaktadır ve dolayısı ile atlanması pek muhtemeldir. Özellikle malignitesi ve immünsupresyonu olan ve yüksek ateş ile acil servise gelen hastalarda batın içi enfeksiyon ve dalak absesini de ayrıcı tanıda akılda tutmak gerektiği düşüncesindeyiz. Özellikle geçirilmiş cerrahisi olan hastalarda sepsis bulguları intrabdominal enfeksiyonu hatırlatmaldır. Bu hasta grubu hızlı değerlendirilip, tanıya gidilecek prosedürlerden sonra multidisipliner yaklaşım ile uygun cerrahi yada palyatif tedavilere yönlendirilmelidir.

\section{Çıkar Çatışması}

Yazarlar herhangi bir çıkar çatışması bildirmemişlerdir.

\section{KAYNAKLAR}

1. Ulhaci N, Meteoglu I, Kacar F, Ozbas S: Abscess of the spleen. Pathol Oncol Res 2004;10:234-6.

2. Fotiadis $C$, Lavranos $G$, Patapis $P$, Karatzas $G$ : Abscesses of the spleen: report of three cases. World J Gastroenterol 2008;14:3088-91.

3. ChangKC, Chuah SK, Changchien CS, Tsai TL, Lu SN, Chiu VC,et al. Clinical characteristics and prognostic factors of splenic abscess: a review of 67 cases in a single medical center of taiwan. World J Gastroenterol 2006;12:460-4.

4. Tikkakoski $T$, Siniluoto $T$, Päivänsalo $M$, Taavitsainen $M$, Leppänen $M$, et al. Splenic abscess. Imaging and intervention. Acta Radiol. 1992;33:561-5. 